\title{
A new Late Devonian isoetalean lycopsid from New South Wales, Australia: Cymastrobus irvingii gen. et sp. nov.
}

\author{
Mathilde Evreïnoff, Brigitte Meyer-Berthaud, Anne-Laure Decombeix, Renaud \\ Lebrun, Philippe Steemans, and Paul Tafforeau
}

\begin{abstract}
In Australia, lycopsids are abundant in early land plant assemblages, leading to the concepts of a "Baragwanathia flora" extending from the late Silurian to the Early Devonian, and a "Leptophloeum flora" characterizing the Late Devonian. Yet, the taxonomic status and systematic affinities of a large number of lycopsid remains from the Devonian of Australia are poorly resolved. The contribution of such lycopsids to the diversification of the group and the evolution of the rhizomorphic lycopsids is unknown. In this paper we investigate the three-dimensional organization of a new structurally preserved cone using $\mathrm{X}$-ray synchrotron microtomography. This large and compact bisporangiate cone, which was collected at Barraba, a Famennian locality in northern New South Wales, represents a new genus, Cymastrobus. Its sporophylls are comprised of a poorly preserved lamina and a long narrow pedicel enlarging distally and possessing an abaxial keel and a heel. Megasporangia contain a large number of megaspores. Their central body shows several rows of small circular structures surrounding the trilete mark. Microspore remains are of the Endosporites-type. Cymastrobus is close to the contemporaneous genus Bisporangiostrobus and to the Carboniferous taxon Flemingites. It may have occupied a basal position in the phylogeny of the rhizomorphic lycopsids.
\end{abstract}

Mathilde Evreïnoff. Amap - BotAnique et Modélisation de l'Architecture des Plantes et des végétations, CNRS, CIRAD, INRA, IRD, Université de Montpellier, Montpellier, France. mevreinoff@gmail.com Brigitte Meyer-Berthaud. Amap - BotAnique et Modélisation de l'Architecture des Plantes et des végétations, CNRS, CIRAD, INRA, IRD, Université de Montpellier, Montpellier, France.

meyerberthaud@cirad.fr

Anne-Laure Decombeix. Amap - BotAnique et Modélisation de l'Architecture des Plantes et des végétations, CNRS, CIRAD, INRA, IRD, Université de Montpellier, Montpellier, France.

anne-laure.decombeix@cirad.fr

Renaud Lebrun. Institut des Sciences de l'Evolution de Montpellier, CNRS, IRD, Université de Montpellier, Montpellier, France. renaud.lebrun@umontpellier.fr

Evreïnoff, Mathilde, Meyer-Berthaud, Brigitte, Decombeix, Anne-Laure, Lebrun, Renaud, Steemans, Philippe, and Tafforeau, Paul. 2017. A new Late Devonian isoetalean lycopsid from New South Wales, Australia: Cymastrobus irvingii gen. et sp. nov.. Palaeontologia Electronica 20.3.47A: 1-16

palaeo-electronica.org/content/2017/2012-devonian-lycopsid-cone

Copyright: September 2017 Palaeontological Association. This is an open access article distributed under the terms of AttributionNonCommercial-ShareAlike 4.0 International (CC BY-NC-SA 4.0), which permits users to copy and redistribute the material in any medium or format, provided it is not used for commercial purposes and the original author and source are credited, with indications if any changes are made.

creativecommons.org/licenses/by-nc-sa/4.0/ 
Philippe Steemans. Département de Géologie, Unité de recherche PPP, Université de Liège, Campus du Sart Tilman, Quartier Agora, Allée du 6 Août, 14, Bât. B-18, B-4000 Liège 1, Belgium.

p.steemans@ulg.ac.be

Paul Tafforeau. European Synchrotron Radiation Facility, 71 avenue des Martyrs, CS-40220, F-38043

Grenoble cedex 09, France. paul.tafforeau@esrf.fr

Keywords: Palaeozoic; Gondwana; Lycopsida; reproductive organ; new genus; new species

Submission: 10 March 2017 Acceptance: 14 September 2017

\section{INTRODUCTION}

Lycopsids are iconic in the early floral assemblages of Australia for their antiquity and abundance. The age of Baragwanathia, a genus which consists of robust leafy axes from Victoria, has long been debated, but it is now accepted that its oldest remains date from the early Ludlow (Late Silurian; Lang and Cookson, 1935; Rickards, 2000). The lycopsids succeeding Baragwanathia in Australia are poorly known, and their age is not always well constrained. Hill et al. (1999) report a diversification in systematics paralleled by one in growth habit in floras of late Early to early Late Devonian age (late Emsian to Frasnian). The herbaceous lycopsids of this time interval are assigned to Leclercqia complexa (Fairon-Demaret, 1974; Meyer-Berthaud et al., 2003). Those identified in the Eifelian locality of Storm Hill in the Broken River area of north-eastern Queensland, are a good example. Larger axes have been referred to as Protolepidodendron, ?Lepidodendron and Lepidosigillaria but these taxonomic determinations need to be reassessed (Gould, 1975; White, 1986). A Lepidosigillaria-like trunk base reaching $14 \mathrm{~cm}$ in width was discovered in the Givetian-Frasnian Bunga beds of Bunga Pinch quarry, on the south coast of New South Wales. This report shows that Australian lycopsids had already reached a small tree habit by then (Young, 2007; Meyer-Berthaud et al., 2016).

In the Late Devonian, the Australian lycopsids seem poorly diversified. Most remains consist of axial fragments of Leptophloeum, a genus of worldwide palaeogeographical distribution that may have thrived in shoreline environments (Hill et al., 1999). Despite a lack of detailed information concerning the largest stems of Leptophloeum, this genus is viewed as arborescent, with trunks thought to have reached $50 \mathrm{~cm}$ in diameter and 10$25 \mathrm{~m}$ in height (Lemoigne, 1982; Li et al., 1986; Taylor et al., 2009). These trees are reconstructed with a cormose base (Prestianni and Gess, 2014) and lateral branches produced along the trunk
(Wang et al., 2005). Their fructifications are interpreted as narrow strobili with peltate sporophylls (Walton, 1925-26; Li et al., 1986).

The Famennian plant locality of Barraba, in north-eastern New South Wales, is one of the rare Devonian sites of Australia to have yielded permineralized plants. In addition, a large number of vegetative axes of Leptophloeum are preserved as adpressions. Two permineralized specimens of lycopsids have been collected in this locality (Chambers and Regan, 1986). One is the large cone reported in the present paper, the second a lycopsid stem that Chambers and Regan referred to as Leptophloeum and that we are currently investigating. The Barraba cone is the single lycopsid fructification yet published from any Late Devonian plant locality in Australia. Because of the rarity of this type of remains, we have chosen to use XRay Synchrotron microtomography to investigate its three-dimensional structure and to discard, as far as possible, any of the destructive methods (i.e., peel-sections, thin-sections) classically employed to study anatomically preserved specimens. This cone represents a new taxon whose affinities are discussed.

\section{MATERIAL}

The cone was collected by Mr. John Irving in 1964 at Barraba, in the New England part of New South Wales, after a record flood of the Manilla River which exposed new outcrops. The plant beds occur on the south-east side of the town, on the left bank of the Manilla River upstream from the Connors Creek crossing. In addition to the cone, the anatomically preserved specimens collected by Mr. Irving consisted of three stems of Polyxylon australe (Chambers and Regan, 1986; Meyer-Berthaud et al., 2007), a few woody specimens, and a lycopsid axis. Permineralized specimens representing diverse groups of euphyllophytes were collected subsequently by two of us during the two field trips we made to Barraba (BMB with Philippe Gerrienne in 2004, BMB and ALD in 2013). During 
these visits, we did not find any new anatomically preserved specimens of lycopsids, whether vegetative of fertile, but we observed abundant impressions of Leptophloeum australe in the intercalated shaly beds. The cone is housed at the Museum Victoria, Melbourne, under number NMVP 161998.

There has been no detailed stratigraphical study of the plant locality itself. The rocks surrounding Barraba have been assigned to the Mandowa Mudstone, a formation whose age ranges from the late Famennian to the Tournaisian. The majority of the Mandowa mudstone sites in the New England Fold Belt are Late Devonian in age based on conodonts (Manilla 1:250,000 sheet of the geological map; Chestnut et al., 1973). In a short report on two trilobites found by Mr. Irving in association with the fossil plants, Wright (1988) assigned a late Famennian age to the locality. This was based on the occurrence of the Tournaisian conodont Siphonodella quadruplicata near the bridge over the Manilla River immediately northwest of Barraba, in beds that appear much higher stratigraphically than those yielding the plants and the trilobites. Recent work on the Mandowa Mudstone south of Barraba suggests that the depositional environment was a marine shelf distal to the continental slope (Vickery et al., 2010).

\section{METHODS}

The propagation phase-contrast X-ray synchrotron microtomography of the cone was obtained by one of us (PT) in 2007 on the beamline ID17 at the European Synchrotron Radiation Facility (ESRF), Grenoble, France. The data were acquired with a beam set of $90 \mathrm{keV}$ and a propagation distance of $5 \mathrm{~m}$ between the specimen and the detector. Voxel size is $31 \mu \mathrm{m}$. The resulting images were cropped with the Fiji software (Image $\mathrm{J} 1.45$, NIHC) and corrected manually to remove external elements such as air bubbles or traces of glue adhering to the fossil. The 3-D images of the cone were reconstructed with the Avizo v.7 software, VSG@. Two sporophyll-sporangium units were virtually extracted from the rest of the cone using Avizo segmentation tools, and subsequently visualized with volume rendering. The measurements were first made in pixels with Fiji then compared with those made in millimeters with Avizo.

A fragment of the cone axis outcropping in the distal part of the specimen was collected, cut transversally, and a thin-section was prepared. This section shows the vascular and inner cortical tissues.

Three-dimensional internal casts of megaspores and microspores were manually extracted from the sporangia and observed in Scanning Electronic Microscopy at the University of Montpellier.

\section{SYSTEMATIC PALAEBOTANY}

\author{
Class LYCOPSIDA Scott, 1909 \\ Order ISOETALES Meyen, 1987 \\ Family INCERTAE SEDIS
}

Genus CYMASTROBUS Evreïnoff, Meyer-

Berthaud, Decombeix, Lebrun, Steemans,

Tafforeau gen. nov.

Type species. Cymastrobus irvingii Evreïnoff, Meyer-Berthaud, Decombeix, Lebrun, Steemans, Tafforeau sp. nov.

Derivation of name. From kyma, the ancient Greek for wave. The generic name, Cymastrobus, refers to the wavy outline of the primary xylem cylinder of the cone axis.

Diagnosis. As type species, see below:

Cymastrobus irvingii Evreïnoff, Meyer-Berthaud, Decombeix, Lebrun, Steemans, Tafforeau sp. nov. Figures 1-5

Diagnosis. Large bisporangiate cone that may exceed $8 \mathrm{~cm}$ long and $5 \mathrm{~cm}$ wide. Cone axis narrow, about $10 \%$ the width of the cone, containing a ring of primary xylem showing a corrugated outline with an almost continuous band of exarch protoxylem; sporophyll traces departing from the bays of the primary xylem cylinder. Sporophyll-sporangium units arranged helically, about 8-10 per gyre. Sporophylls comprised of a long, narrow pedicel widening distally but without alations, and a delicate distal lamina oriented perpendicularly to the pedicel; pedicels showing an abaxial keel and a distal heel, the latter forming hexagonal shields protecting the sporangia externally. Megasporangia and microsporangia in distinct parts of the cones; megasporangia proximal, enclosing a large number of megaspores. Casts of megaspore central body up to $500 \mu \mathrm{m}$ in diameter, showing numerous small circular pores arranged in several rows around the trilete mark, smooth elsewhere. Casts of microspore central body less than $100 \mu \mathrm{m}$ in diameter, showing one small pore between the rays of the trilete mark.

Holotype. Specimen NMVP 161998, Museum Victoria, Melbourne, Victoria, Australia.

Type locality. Barraba, New England, New South Wales, Australia; left bank of the Manilla River, upstream from the Connors Creek crossing, Mandowa Mudstone.

Age. Famennian. 

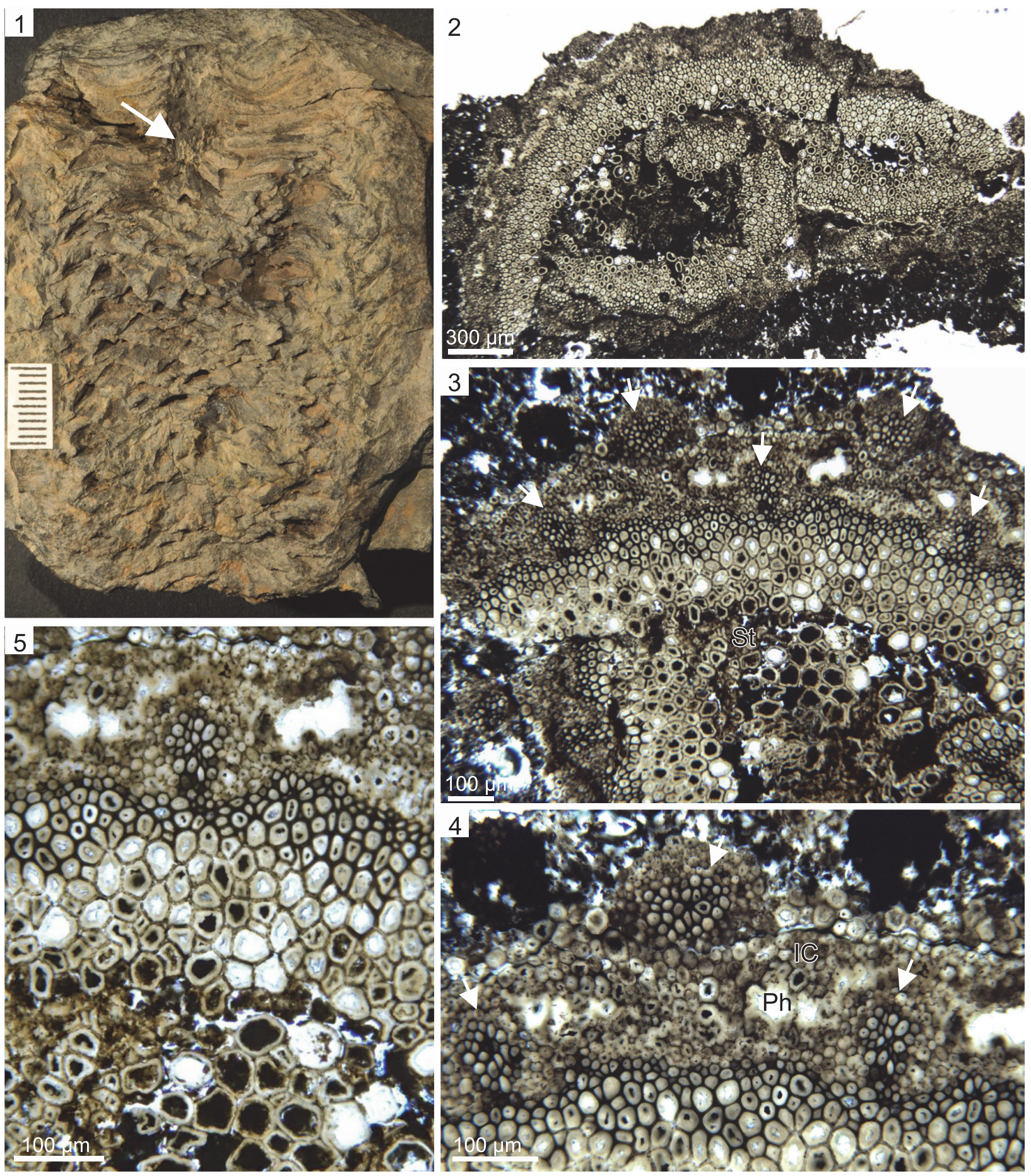

FIGURE 1. Cymastrobus irvingii gen. et sp. nov. NMVP 161998. 1, General view of the cone; cone axis at arrow. 2, Distal part of cone axis in transverse section. 3, Detail showing the stele (St) and five sporophyll traces at arrows. 4, Detail showing the wavy outline of the xylem ring, presumed location of the phloem ( $\mathrm{Ph}$ ), inner cortical cells (IC) and three sporophyll traces at arrows. 5, Detail showing the emission of a sporophyll trace from a groove of the primary xylem ring. 
Derivation of name. In honor of Mr. John Irving who discovered the Barraba plant locality and collected the cone.

\section{Description}

General features. The bisporangiate cone is 7.5 $\mathrm{cm}$ long and $5.8 \times 2 \mathrm{~cm}$ wide (Figures $1.1,2.1$ ). It is incomplete, the proximal and distal extremities being missing. It has been laterally compressed through its whole length and distorted distally (Figure 2.2). A split in the distalmost part reveals the cone axis (Figure 1.1). Sporophylls are helically arranged. On the compressed face, however, they may appear organized in vertical rows (Figure 2.4, 2.8). The megasporophylls occupy the basal third of the cone, a zone about $2.8 \mathrm{~cm}$ long (Figure 2.1, 2.2, 2.5, 2.6, 2.7). Apart from their spore content, the mega- and microsporophylls are similar in shape and size.

Cone axis. The cone axis measures about $6 \mathrm{~mm}$ in its widest dimension. It does not show any conspicuous tapering from one end to the other (Figure 2.1, 2.2). In transverse section, the stele which is broken in the distal part is $1.8 \times 2.6 \mathrm{~mm}$ wide (Figures 1.2, 2.3). It shows a $250 \mu \mathrm{m}$ thick ring of primary xylem surrounding a central zone where a group of large thin-walled cells remains preserved (Figure 1.3, 1.5). These pith cells measure 40-55 $\mu \mathrm{m}$ in diameter. The outer edge of the xylem ring is irregularly undulated. Protoxylem tracheids form an almost continuous band of 9-15 $\mu \mathrm{m}$ wide cells at the periphery (Figure 1.3-5). Metaxylem tracheids increase from 20 to $48 \mu \mathrm{m}$ in diameter inwards. Outside the ring of primary xylem and separated from it by a $40 \mu \mathrm{m}$ thick zone of small thin-walled cells, are pockets of poorly preserved elements that may have corresponded to the primary phloem (Figure 1.4, 1.5). Beyond, a narrow band of 16-30 $\mu \mathrm{m}$ wide cells represents the inner cortex.

Vascular traces to the sporophylls are numerous and produced helically (Figure 2.3). They depart from the grooves of the corrugated xylem cylinder (Figure 1.3-5). At the level of emission, their section tends to be radially elongated (Figure 1.5). They measure about $60 \mu \mathrm{m}$ tangentially and $80 \mu \mathrm{m}$ radially, and are comprised of about 20-24 tracheids. Vascular traces increase in size as they cross the cortex. On the outer edge of the inner cortex their xylem strand is $85-90 \mu \mathrm{m}$ wide and has a circular outline. It is bordered on the abaxial side by a $40-50 \mu \mathrm{m}$ wide crescent-shaped sheath of thin-walled cells that do not exceed $13 \mu \mathrm{m}$ in diameter (Figure 1.4). The traces follow a steep course upwards in the rest of the cortex until they reach the base of the sporophylls (Figure 2.2). Their diameter in the outer cortex is about $140 \mu \mathrm{m}$ (Figure 2.3).

Sporophyll-sporangium units. The sporophyllsporangium units are tightly packed (Figure 2.1). Their number per gyre is estimated to range between eight and 10 . They are slightly raised in the distalmost part of the cone, diverge from the axis at approximately $90^{\circ}$ lower down, and bend downward progressively in the lower half, with an angle of up to $115^{\circ}$ in the megasporangiate part (Figure 2.1, 2.2).

Sporophylls comprise a $19-22 \mathrm{~mm}$ long pedicel and a poorly preserved distal lamina consisting of dissected threads of tissues oriented perpendicularly to the pedicel (Figures 3.2-5, 4.1-7). Pedicels are narrow (Figures 2.5-6, 4.3) but expand both laterally and abaxially in the second half of their length (Figures 2.6-8, 3.3-4, 4.3). They are $200 \mu \mathrm{m}$ wide proximally and reach a maximal width of 5.5 $\mathrm{mm}$ distally (Figures $2.8,3.4-5$ ). In profile view, the pedicels are about $500 \mu \mathrm{m}$ high when they diverge from the cone axis. At about $3 \mathrm{~mm}$ from their insertion point, they differentiate a keel on the abaxial side (Figure 3.2). The keel increases in size distally until it fuses with a heel reaching a height of $4 \mathrm{~mm}$ (Figures 3.2, 4.4-7). In front view, the distal parts of the pedicels form diamond-shaped shields partly hiding the sporangia (Figure 2.4). A single vascular strand runs through the whole length of the pedicels. In the lamina, synchrotron images show it as a vertical structure of low density that stands in central position among the surrounding threads of laminar tissue (Figures 2.1, 3.5, 4.1-5).

The sporangia measure 16-18 mm long, 3-5 $\mathrm{mm}$ high, and 4-6 $\mathrm{mm}$ wide (Figures 2.2, 3.4-5, 4.4-7). They are slightly shorter than the pedicels to which they are attached over their whole length by a narrow pad of tissue (Figure 3.4-5). Their width exceeds that of the pedicels in their proximal half and becomes comparable distally, except at the tip where the sporangia become narrower (Figures 2.5-8, 3.4-5, 4.1-2). Sporangium wall is thin $(80-90 \mu \mathrm{m})$. All the sporangia have retained their spore contents. The mega- and microsporangia both contain several hundred spores (Figures 2.2, 2.5-7, 4.1-2, 4.6, 4.7).

Spores. The internal casts of megaspores collected inside the megasporangia have a spherical outline and measure 420-490 $\mu \mathrm{m}$ in diameter (Figure 5.1). They do not show any ornamentation except on the proximal face where a faint trilete mark characterized by $100 \mu \mathrm{m}$ long rays is surrounded by a triangular area with concave sides 

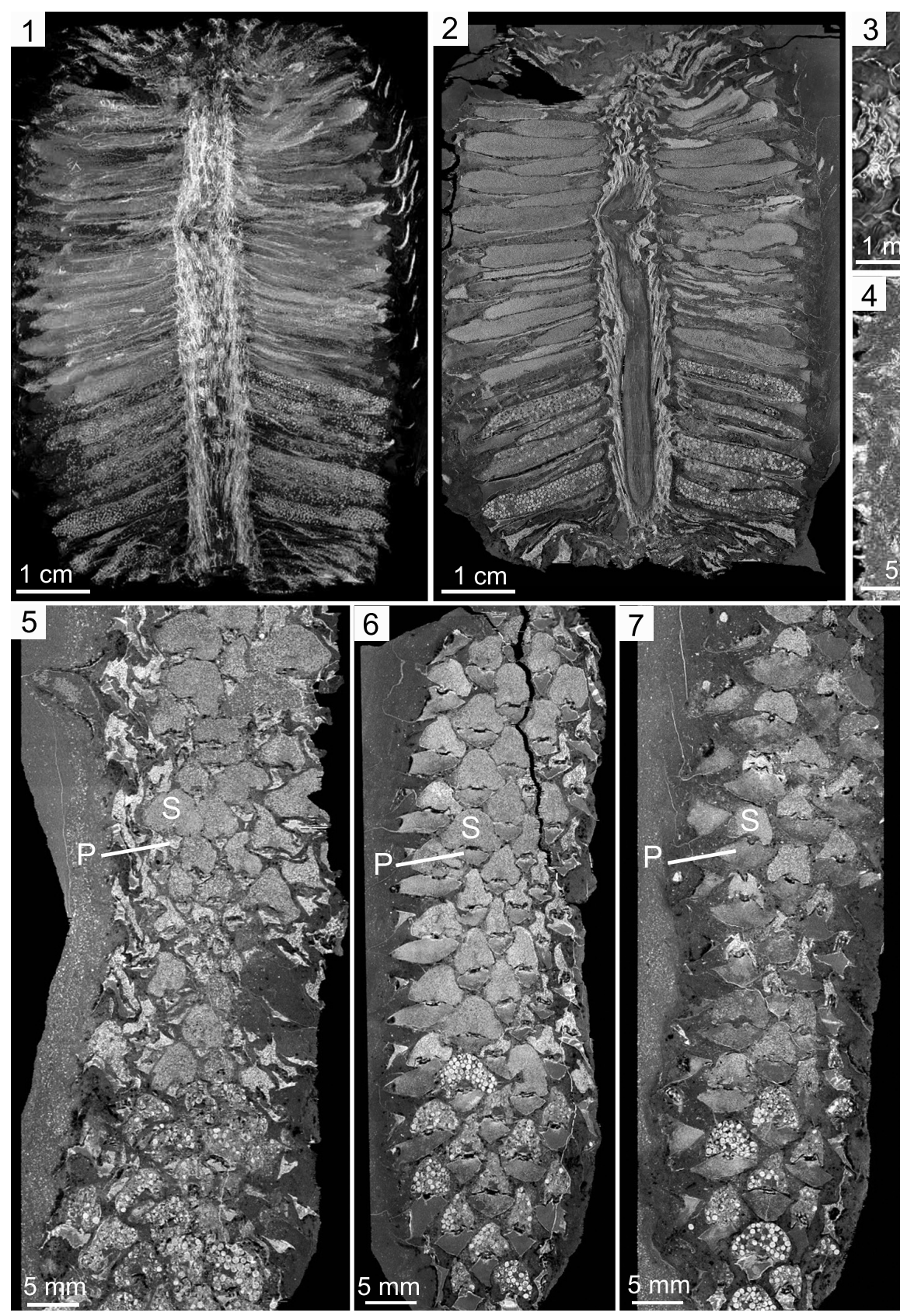

FIGURE 2. Cymastrobus irvingii gen. et sp. nov. NMVP 161998. Virtual sections, X-Ray synchrotron microtomography. 1, Cone in tangential section. 2, Cone in radial section; note the proximal position of the megasporangia. 3, Cone axis in transverse section. 4, Outer portion of the cone in tangential section showing four sporophyll-sporangium units in longitudinal row. 5-8, Inwards to outwards series of tangential sections through the cone showing the progressive changes in size of the sporophyll pedicels $(P)$ and the sporangia $(S)$.

showing more than a hundred pores (Figure 5.2). Individual lobes of this trilobed pored zone are about $140 \mu \mathrm{m}$ long and $85 \mu \mathrm{m}$ wide. The pores are regularly arranged in three to four rows on each side of the rays. They are circular to oval and 2-3 $\mu \mathrm{m}$ deep. Their diameter ranges from $4 \mu \mathrm{m}$ close to the rays, up to $9 \mu \mathrm{m}$ outside.
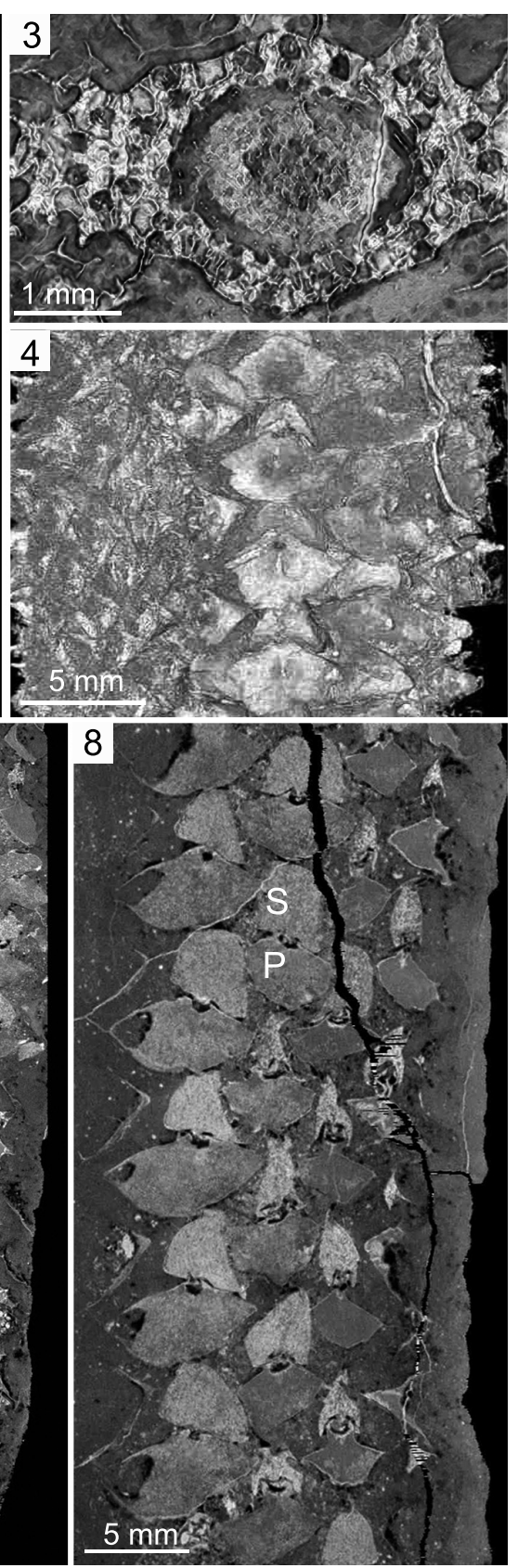

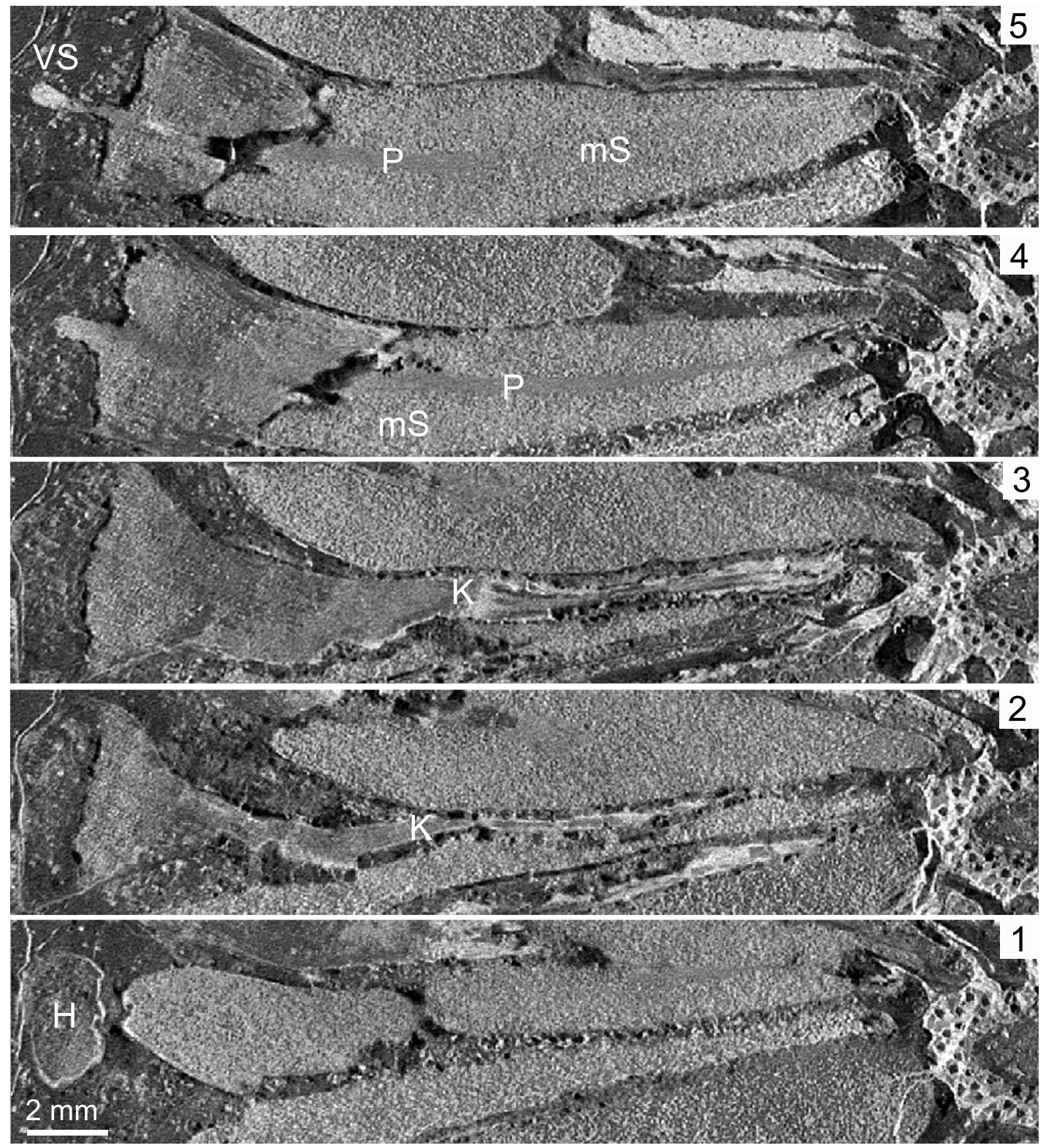

FIGURE 3. Cymastrobus irvingii gen. et sp. nov. NMVP 161998. Virtual sections, X-Ray synchrotron microtomography. 1-5, Proximal-distal series of longitudinal sections through a sporophyll-sporangium unit; note the heel $(H)$ in $\mathbf{1}$, keel $(\mathrm{K})$ in $\mathbf{2}$ and $\mathbf{3}$, microsporangium (mS) and longitudinal pad of tissue $(\mathrm{P})$ in $\mathbf{4}$ and $\mathbf{5}$, vascular strand $(\mathrm{VS})$ in $\mathbf{5}$.

lope showing densely arranged minute pores on the inner side.

\section{DISCUSSION}

\section{General Features}

The Barraba specimen lacks its proximal and distal parts and one may wonder whether it actually represents a large bisporangiate cone or a fertile region with alternating mega- and microsporangiate zones such as those described in the family Chaloneriaceae (Pigg and Rothwell, 1983a, 1983b; Pigg, 1992). Sporophylls in the Barraba specimen tend to bend downwards proximally, upwards distally, and are almost horizontal in between. Such variation in the orientation of the lateral organs is observed at the apices of axes. This feature suggests that the Barraba specimen is a cone terminating an axis rather than a fertile zone intercalated between the vegetative portions of a growing axis.

The Barraba cone shows a narrow axis whose diameter represents about $1 / 10$ of the total diameter of the cone. In transverse section, the stele is 

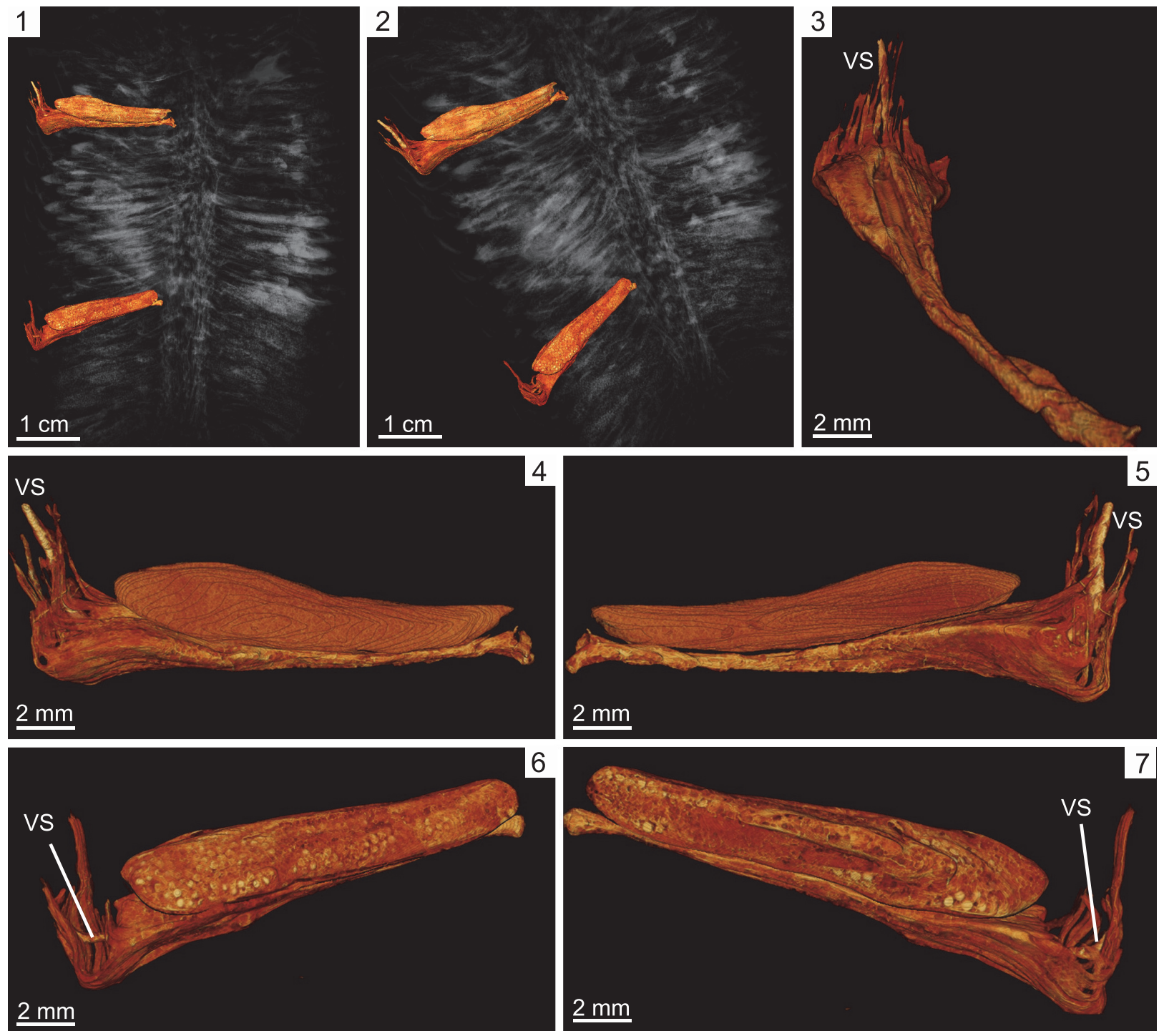

FIGURE 4. Cymastrobus irvingii gen. et sp. nov. NMVP 161998. Virtual reconstructions and volume rendering visualization of chosen anatomical units within the X-Ray synchrotron microtomography scan. 1-2, General view of the cone showing two reconstructed sporophyll-sporangium units, the proximal one producing megaspores, the distal one microspores. 3, Reconstructed sporophyll showing the enlarging pedicel and dissected lamina. 4-5, Two reconstructed sporophyll-microsporangium units in profile view. 6-7, Two reconstructed sporophyll-megasporangium units in profile view. VS: vascular strand.

comprised of a wide central zone of thin-walled cells surrounded by a solid ring of primary xylem. Its outer border is irregularly corrugated and shows departing sporophyll traces in the furrows. Broadly comparable primary vascular anatomies have been recorded in Sigillaria, Lepidophloios, and Chaloneria (Bertrand, 1891; Delevoryas, 1957; DiMichele et al., 1979), but also in a few Mississippian taxa of more restricted palaeogeographical occurrences such as Linietta, Lycopogenia, and Winslowia, which all have lobed steles (Roy and Matten, 1989; Dunn et al., 2012). Despite their superficial resemblances, the trace emission pat- terns of these genera are different. Trace emission in the Barraba cone looks closer to the pattern observable in the chaloneriacean genera Chaloneria and Winslowia, and called "invaginate" by Bateman et al. (1992). The protoxylem of these genera, however, is dissected and does not form a continuous band at the periphery of the primary xylem like in the Australian specimen.

The Australian cone bears eight to 10 sporophyll-sporangium units per gyre. The sporophylls consist of an elongated pedicel and an upturned lamina. The pedicels possess an abaxial keel and a heel. They lack any lateral expansion or alation 

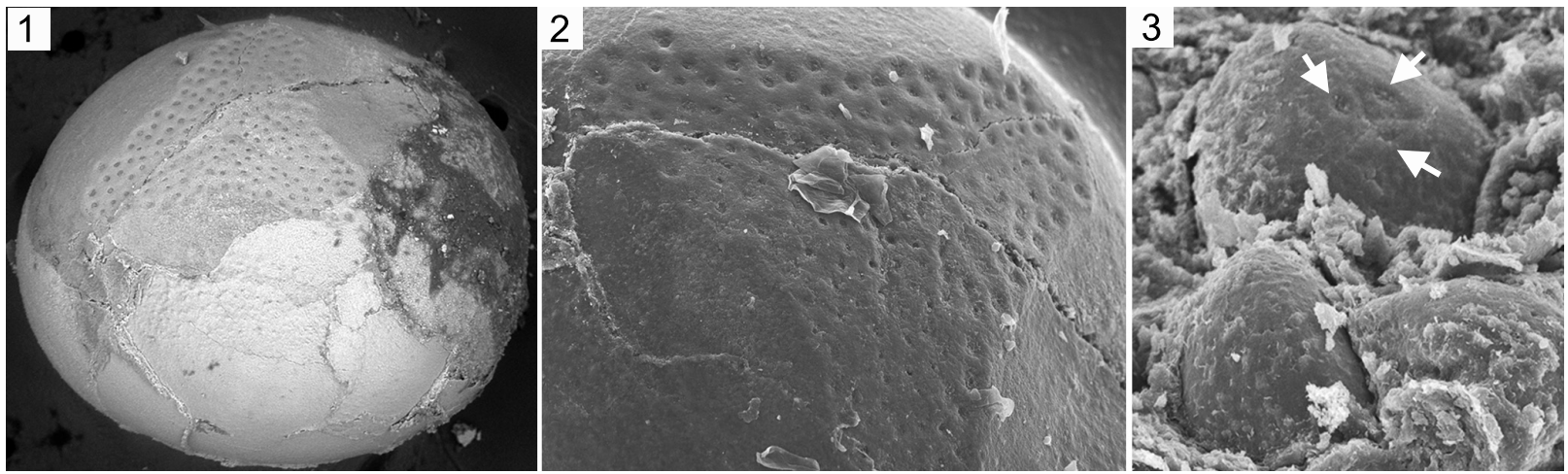

FIGURE 5. Cymastrobus irvingii gen. et sp. nov. NMVP 161998. 1, Cast of a megaspore central body showing numerous small circular pores arranged in several rows around the trilete mark. 2, Detail of previous view. 3, Casts of microspore central bodies; the largest one shows three pores between the rays of the trilete mark (arrows).

and are narrower than the sporangia attached to their adaxial surface except in the distal part. The laminae are represented by short portions of dissected tissue suggesting that they were devoid of any strengthening cells. They were easily torn away, including when the spores were still contained in the sporangia. Sporangial protection during the early developmental stages of the cone may have been provided by the distal part of the pedicels, especially the heel, rather than by the evanescent laminae (Figure 4). The megasporangia contain a large number of megaspores.

\section{Spores}

The spores of the Barraba cone present a wall consisting of an outer envelope and a central body whose cast is the only structure that could easily be extracted and analyzed. The pores on the proximal surface of the central body represent the imprints of the structures that attached it to the outer envelope. These structures have been called "papillae", "cushions", "verrucae", dark spots, etc. in other lycopsid spores (Bharadwaj and Tiwari, 1970; Brack and Taylor, 1972; Grauvogel-Stamm and Lugardon, 2004). Detailed ultrastructural studies of the spore walls of some extant and extinct Isoetaceae and Selaginellaceae showed that these papillae correspond to multilamellate zones formed at an early stage of wall development (Lugardon et al., 1999, 2000). Grauvogel-Stamm and Lugardon (2004) suggested that these papillae have the same developmental origin in all the lycopsid taxa where they occur.

With their rows of papillae surrounding the trilete mark, the central bodies of the Barraba megaspores are comparable to those of the sporae dispersae Duosporites, Pilatriletes, Surangeaesporites and Talchirella (Bharadwaj and Tiwari, 1970;
Grauvogel-Stamm and Lugardon, 2004). These isolated megaspores are common in Permian and Triassic assemblages of Gondwana. In older deposits, dispersed spores with similar features on the proximal face are rarer. They include Pustulatisporites distalis from a Late Devonian spore assemblage of Sichuan, China (Lu, 1981; Chitaley and McGregor, 1988) and Triangupapillaesporites biseratus from a Visean locality of England (Spinner, 1982). The central body casts of the Barraba microspores are assignable to the genus of sporae dispersae Endosporites that ranges from the Late Devonian to the Permian (Brack and Taylor, 1972), and specifically to E. papillatus and E. pseudopapillatus (Grauvogel-Stamm and Lugardon, 2004). In the microspore genus Lycospora, which has been found in a large range of mono- and bisporangiate lycopsid cones (Brack-Hanes and Thomas, 1983; Traverse, 2008), one species of early Pennsylvanian age, L. rugulosa, has also been reported with three apical papillae on the central body (Bek, 2012). The microspores of $L$. rugulosa, however, differ by the distal ornamentation of their central body which is rugulate.

Microspores with interradial papillae, laminated zones or pores, have been recorded in the sporangia of a large number of extant and extinct taxa assignable to the Isoetaceae (e.g., Isoetes, Pleuromeia, Annalepis), the Chaloneriaceae (Chaloneria, Polysporia, Sporangiostrobus / Omphalophloios), the Lepidodendraceae (Flemingites, Mazocarpon, Sigillariostrobus), and other lycopsids of uncertain affinities (e.g., Bisporangiostrobus, Porostrobus), but also to the Selaginellaceae (Chaloner, 1953, 1958; Bharadwaj, 1958; Chitaley and McGregor 1988; Grauvogel-Stamm and Lugardon, 2004; Bek and Leary, 2012). Megaspores with interradial papillae, laminated zones or pores, are 
not found in any extant taxa. Their occurrence in the Chaloneriaceae and the Lepidodendraceae is not as well documented as that of the microspores but such megaspores also occur in taxa that belong to both the rhizomorphic lycopsids and the Selaginellaceae (Grauvogel-Stamm and Lugardon, 2004, table 1). In addition to the Barraba strobilus, the oldest cones possessing such megaspores are assigned to Bisporangiostrobus, a Famennian genus of uncertain affinities (Chitaley and McGregor, 1988). Overall, this evidence suggests that the papillae attaching the central body to the outer envelope of lycopsid spores evolved within the heterosporous lycopsids at a deep node of the phylogenetic tree, before the split between the rhizomorphic lycopsids and the Selaginellaceae (Kenrick and Crane, 1997). Following this hypothesis, this character has either been lost in some derived taxa or unidentified because the recognition of papillae, laminated zones or pores is constrained by the preservation state of the spores and the chemical treatment used for their analysis (Grauvogel-Stamm and Lugardon, 2004). The alternative possibility is that this character evolved several times independently within the heterosporous lycopsids. In both cases, the possession of spores with papillae, laminated zones or pores on their central body appear as a poor indicator of the systematic affinities of the reproductive structures that produced them.

\section{Comparison with Devonian and Carboniferous Lycopsid Cones}

The record of Devonian cones assignable to the lycopsids has greatly increased in the last 20 years and currently comprises about 15 taxa ranging from the Givetian (Senkevitsch et al., 1993; Cai and Chen, 1996; Hao et al. 2007) to the late Famennian (Fairon-Demaret, 1977; Chitaley and McGregor, 1988). A majority of these fructifications, however, differs markedly from the Australian cone by their slender shape and smaller size, by the morphology of their sporophyll-sporangium units, and by their sporangial content. For example, the cones of the Givetian genus Longostachys (Cai and Chen 1996) and the Famennian genus Barsostrobus (Fairon-Demaret, 1977), which are morphologically close, exceed $14 \mathrm{~cm}$ in length but are less than $1 \mathrm{~cm}$ wide. Their sporophylls are spoon-like proximally, with a globose to elliptical sporangium on the adaxial surface. They retain a long and lanceolate distal lamina. They may have been monosporangiate. The Longostachys megasporangia contain only four megaspores cor- responding to the dispersed spore genus Laevigatisporites.

The cones of two other Devonian genera, which differ markedly from the Barraba cone, are those of Changxingia (Wang et al., 2014) and Minostrobus (Wang, 2001; Meng et al., 2013), both monosporangiate and of Famennian age. The pedicels of their sporophylls possess a keel and a conspicuous heel but, unlike those of the Barraba cone, they are short (less than $5 \mathrm{~mm}$ in length) and show distal alations. Their megasporangia contain only four megaspores of Lagenicula type.

Cones of the Givetian genera Mixostrobilus and Yuguangia are heterosporous like the Barraba specimen but they are more slender, the laminate part of their sporophylls is much more important, their sporangia are ellipsoidal or globose rather elongate, and both genera contain a small number of megaspores within their megasporangia. Indeed, the Mixostrobilus cones, estimated to reach $7 \mathrm{~cm}$ in length, do not exceed $3.5 \mathrm{~cm}$ in width (Senkevitsch et al., 1993). Those of Yuguangia which may be up to $16 \mathrm{~cm}$ long are less than $1 \mathrm{~cm}$ wide (Hao et al., 2007). Mixostrobilus mega- and microsporangia are irregularly arranged and not separated in well-differentiated zones as in the Barraba cone. They are attached to the sporophylls by a short central stalk. Sporophylls of Yuguangia cones show a short pedicel and a relatively long lamina. The heel, as shown on Hao et al.'s (2007, figure 4) reconstruction, actually corresponds to a deflection, rather than a distal thickening, of the pedicel. Finally, in the cone axis of both Mixostrobilus and Yuguangia, the outline of the primary xylem is not undulated as in the Barraba cone. Sporophyll traces in these genera depart from the small protoxylem ridges protruding on the outer border of the metaxylem.

The reproductive parts of Leptophloeum, a Late Devonian genus represented by abundant compression remains at Barraba, have never been described in detail, and their arrangement in cones or in fertile regions is uncertain (Wang et al., 2005). However, the few characters reported for these reproductive parts are unlike the Barraba cone. They are more slender, with a diameter that does not exceed $3 \mathrm{~cm}$, and they consist of peltate sporophylls which, in the illustrations provided by Walton (1925-1926) and Li et al. (1986), show very short pedicels compared to the diameter of the "cone" axis. The sporangia and their spore content are unknown. The outline of the primary xylem of the Leptophloeum axes illustrated by Geng (1990) and Wang et al. (2005) is not undulated as in the Bar- 
raba cone but shows small ridges of protoxylem at the origin of the leaf traces.

Fertile structures of lycopsid affinities resembling the Barraba specimen, i.e., that are relatively large, bisporangiate, have elongated sporangia attached over their whole length on narrow pedicels, and produce a large number of megaspores per megasporangium, have not been reported prior to the late Late Devonian. As detailed below, they belong to a large range of taxa including a few genera of Famennian age whose affinities are uncertain (Jurinodendron, Clevelandodendron, Bisporangiostrobus) and genera resolved as basal in Bateman et al.'s (1992) phylogenetic analysis of the arborescent lycopsids from the Carboniferous of Euramerica. Among the latter are Flemingites (Brack-Hanes and Thomas, 1983) and genera affiliated to the Chaloneriaceae (Pigg and Rothwell, 1983a, 1983b). The bisporangiate cones with elongated sporangia of the small-sized, pseudoherbaceous Carboniferous genera Oxroadia and Paurodendron are not considered in the following comparisons because they are much smaller than the Australian strobilus, show an evaginate pattern of sporophyll trace emission, and contain only a few megaspores per megasporangium (Schlanker and Leisman, 1969; Bateman, 1992).

The genus Jurinodendron, long known as Cyclostigma and whose best known species is $\mathrm{J}$. kiltorkense from the Famennian of Ireland, was assigned to the Lepidodendrales by Chaloner (1967). Wang et al. (2003) proposed that Jurinodendron, together with Clevelandodendron ohioensis (Chitaley and Pigg, 1996) and Bisporangiotrobus harrisii (Chitaley and McGregor, 1988) represent the basal taxa of a supposedly monophyletic group that they referred to as the "Isoetales sensu stricto." This group would encompass the isoetalean lycopsids characterized by cormose rather than stigmarian rhizomorphs. The sporophylls of $J$. kiltorkense cones resemble those of the Barraba specimen in showing narrow pedicels and elongated sporangia lying on their adaxial surface (Chaloner, 1968). However, unlike the Barraba cone, these sporophylls have pedicels lacking a keel and a heel, and they retain very long linear laminae. The bisporangiate nature of the cones of J. kiltorkense has not been demonstrated.

Clevelandodendron ohioensis is represented by a $125 \mathrm{~cm}$ high individual characterized by an unbranched stem and a non-stigmarian rhizomorph. The stem is terminated by a $9 \mathrm{~cm}$ long, 6 $\mathrm{cm}$ wide bisporangiate cone comparable in size and shape to the Barraba specimen (Chitaley and
Pigg, 1996). Because of the superficial resemblance between these two contemporaneous cones, it could be tempting to hypothesize a similar growth habit for the plants that produced them. The structure of the sporophyll-sporangium units of $C$. ohioensis is unknown but there is enough evidence indicating that the two cones may have been more different than thought at first glance. In C. ohioensis, sporophyll laminae are longer and remain attached to the sporophylls. Megaspores do not exceed $360 \mu \mathrm{m}$ in diameter. Microspores are referrable to the dispersed spore genera Calamospora or Punctatisporites with no special features reported at the level of the trilete mark.

Bisporangiostrobus harrisii is represented by a branching axis bearing two cones from a late Famennian locality of Pennsylvania (Chitaley and McGregor, 1988). The cones resemble the Barraba strobilus in many features. Their axis is narrow. The sporophylls in $B$. harrisii consist of an elongated pedicel showing a prominent keel and heel, and a very short lamina measuring no more than $2.5 \mathrm{~mm}$ long. The megaspores, assigned to the dispersed spore genus Duosporites, have a twolayered exine. Their central body lacks any sculpture except on the proximal surface where a triangular pattern of verrucae occurs in the interradial areas. Likewise, the microspores of $B$. harrisii have a two-layered exine and a central body showing a single dark spot between the rays of the trilete mark. B. harrisii cones, however, do not exceed 1.5 $\mathrm{cm}$ in width and are more slender than the Australian cone. Their axis is protostelic and do not show any central thin-walled cells. Their sporophylls and sporangia are shorter. Their megaspores are much fewer and do not exceed 30 per megasporophyll. The interradial papillate zone of the megaspore central body is more extended. The central body of the microspores has longer rays.

Most bisporangiate cones with narrow sporophyll pedicels of Carboniferous age were referred to the genus Lepidostrobus when first described but have been transferred to Flemingites (Carruthers) Brack-Hanes and Thomas. Indeed, these authors showed that the type-species of Lepidostrobus, L. ornatus, is monosporangiate and corresponds to microsporangiate strobili (Brack-Hanes and Thomas, 1983). Flemingites cones are characterized by megaspores of Lagenicula or Lagenoisporites type and microspores of Lycospora type. They are interpreted as the reproductive structures of arborescent lycopsids with Paralycopodites/ Anabathra-type stems (Bateman et al., 1992). Brack-Hanes and Thomas (1983) recognized 13 
species of Flemingites ranging from the Tournaisian to the Pennsylvanian. An additional species of uncertain age but probably no younger than the Middle Pennsylvanian, F. arcuatus, was later described by Stevens et al. (2010). In addition to $F$. arcuatus, one species of Mississippian age, $F$. scotti, and six Pennsylvanian ones, F. bartletti, $F$. diversus, F. gracilis, F. olryi, F. russellianus, and $F$. schopfii, are represented by cones that are different in shape and more slender than the Barraba specimen. Among these, five species ( $F$. scotti, $F$. diversus, F. gracilis, F. schopfii, F. arcuatus) contain a much smaller number of megaspores per megasporangium (16-29).

The single known specimen of $F$. spectabilis was collected in the Pennsylvanian deposits of Montceau-les-Mines (central France). It resembles the Australian strobilus by its size and the siphonostelic structure of its axis. It is $10.5 \mathrm{~cm}$ long, and its total width including the sporophyll laminae is about $6 \mathrm{~cm}$ (Renault, 1888). The central axis measures about $5 \mathrm{~mm}$ in width. The shape of the sporophylls, however, differs from those of the Barraba specimen. Pedicels are much shorter, measuring less than $10 \mathrm{~mm}$ in length. The laminae, which are retained on the cone, are wide, triangular, and up to $35 \mathrm{~mm}$ long. The number of megaspores per megasporangium is unknown.

Two Flemingites species of Mississippian age, $F$. gallowayi and $F$. noei, contain a large number of megaspores per megasporangium. F. gallowayi is a poorly known species represented by a single adpressed specimen from the Pocono sandstone of Pennsylvania (Arnold, 1933). In this species, as in the Barraba cone, the laminae are not preserved. The F. gallowayi cone, however, is narrower than the Australian specimen. The sporophyll pedicels are shorter and do not exceed $15 \mathrm{~mm}$ in length. The microspores in F. gallowayi show three dark spots between the rays of the trilete mark like those of the Barraba specimen, but the megaspores apparently lack an inner body with interradial verrucae (Chitaley and McGregor, 1988). F. noei is represented by a single anatomically preserved specimen from the New Albany Shale of Kentucky (Mathews, 1940). It is $7 \mathrm{~cm}$ wide, more than $11 \mathrm{~cm}$ long, and differs from the Australian strobilus by the shape of the sporophylls. Indeed, pedicels in F. noei lack a keel and a heel (Mathews, 1940, figure 7). The laminae measure $8 \mathrm{~mm}$ wide, $14 \mathrm{~mm}$ long, and are robust over their whole length. In the cone axis, the vascular traces depart from the protoxylem strands protruding at the periphery of the xylem cylinder. Finally, the megaspores do not exceed $370 \mu \mathrm{m}$ wide and are smaller than those of the Barraba cone.

A number of bisporangiate cones from Mississippian deposits of southern France have been referred to as Lepidostrobus brownii by Zeiller (1911), and later transferred to Flemingites brownii by Brack-Hanes and Thomas (1983). Like the Australian specimen, such cones are large and contain numerous megaspores in their megasporangia. The best studied one, referred to as "the Abbé Théron specimen" by Zeiller (1911) is $11 \mathrm{~cm}$ long and up to $6.2 \mathrm{~cm}$ wide. Its sporophylls appear shorter than those of the Barraba specimen (up to $15 \mathrm{~mm}$ long) and have a distinctive shape that differs from that of the latter specimen. The pedicels do not show a proper heel but, instead, bend downwards abruptly in their distal part before rising up to form a long (up to $20 \mathrm{~mm}$ ) and very thick lamina. In the Australian cone, the deflection of the pedicel is slight if any. Moreover, the pattern of hexagonal shields covering the Abbé Théron specimen in external view corresponds to the distal part of the laminae in transverse section whereas the pattern of diamond-shaped shields covering the Barraba specimen corresponds to the distal part of the pedicels, i.e., the heels.

The family Chaloneriaceae was erected for the Pennsylvanian genera Chaloneria, Polysporia, and Sporangiostrobus (Leisman, 1970; Pigg and Rothwell, 1983a, 1983b). The latter genus was suggested to be a junior synonym of Omphalophloios by Brousmiche-Delcambre et al. (1995). Chaloneriacean plants are characterized by round to lobed cormose bases, leaves attached directly on the axes and not to leaf cushions, and distinctive mega- and microspores (Pigg and Rothwell, 1983a, 1983b). In Sporangiostrobus, the saccate microspores are of the densospore-type (Chaloner, 1962; Bek and Straková, 1995; Opluštil et al., 2010; Bek et al., 2015). In Chaloneria and Polysporia, they are of the Endosporites-type and show interradial papillae on the proximal surface of the central body (Chaloner, 1958; Brack and Taylor, 1972; DiMichele et al., 1979; Pigg and Rothwell, 1983a; Grauvogel-Stamm and Langiaux, 1995). Despite their large size, the possession of Endosporites-type microspores and the fact that the sporophyll lamina are generally unpreserved, the fructifications of the Chaloneriaceae appear different from the Barraba specimen. Indeed, rather than true cones, all these fructifications except Polysporia robusta (Dràbek, 1976) and Polysporia doubingeri (Grauvogel-Stamm and Langiaux, 1995) consist of fertile regions where sporangiate 
and vegetative zones alternate (DiMichele et al., 1979; Pigg and Rothwell, 1983a, 1983b; Wagner, 1989; Brousmiche-Delcambre et al., 1995; Pigg, 2001). Their axial part is wide and represents at least $1 / 3$ of the total diameter of the fructification (Chaloner, 1958). It is much broader than that of the Australian cone. The sporangia in the Chaloneriaceae are shorter than those of the Barraba cone, especially those of Sporangiostrobus / Omphalophloios (Opluštil et al., 2010). They are not protected externally by any differentiated structures like heels and, in the case of compression fossils, they appear uncovered on the rock surface when the distal parts of the sporophylls are missing. The megasporangia of Chaloneria and Polysporia contain numerous megaspores of the Valvisisporites or Pseudovalvisisporites types, unknown to have a central body with any ornamentation around the trilete mark. Unlike those of the Barraba cone, the megasporangia of Sporangiostrobus / Omphalophloios contain only a few tetrads of Zonalesporites-type megaspores. Interestingly, in Sporangiostrobus / Omphalophloios feistmantelii, Bek et al. (2015) record Zonalesporites superbus megaspores showing a central body ornamented with ten rows of "lenticular structures" in the interradial areas. These structures are more numerous and larger (12-15 $\mu \mathrm{m}$ in diameter) than the pores observed in the megaspores of the Australian cone. Nonetheless, they suggest that the possession of proximally ornamented central bodies may have been overlooked in some lycopsid megaspore taxa.

The Barraba specimen is unlike any Late Devonian or Carboniferous lycopsid cone described to date. It represents a new taxon that is not assignable to any known genus and whose affinities are uncertain. It superficially resembles the cone of Clevelandodendron, a contemporaneous plant of limited height characterized by an unbranched habit and a cormose base. When all characters are considered, however, the closest taxon is another contemporaneous genus, Bisporangiostrobus, represented by branched stems thought to belong to an arborescent rhizomorphic lycopsid related to Jurinodendron (Chitaley and Pigg, 1996).

\section{CONCLUSIONS}

A new bisporangiate cone, Cymastrobus irvingii gen. et sp. nov., is described from Barraba (New South Wales, Australia). This is the second species of lycopsids identified at this locality after
Leptophloeum australe which is represented by abundant compression remains.

C. irvingii shows distinctive spores whose walls are composed of a central body attached proximally to an outer envelope by interradial papillae. This character, however, is probably plesiomorphic for the heterosporous lycopsids, and poorly indicative of the phylogenetic affinities of the Barraba plant that produced the Cymastrobus cones.

The large size and compact shape of $C$. irvingii, the morphology of its sporophyll-sporangium units, and the large number of megaspores contained in each megasporangium form a set of features that are unknown in most Givetian to Late Devonian lycopsid cones. C. irvingii compares better to the Famennian genera Clevelandodendron and Bisporangiostrobus, and to the MississippianPennsylvanian genus Flemingites, three taxa suspected to occupy a basal position in the rhizomorphic lycopsid clade (Isoetales sensu Pigg, 2001). This evidence supports the idea of a change in the systematic composition of heterosporous lycopsid assemblages at the end of the Devonian.

\section{ACKNOWLEDGEMENTS}

We are very much indebted to J. Irving, R. Derrick and I. Percival (Geological Survey of New South Wales) for the information they kindly provided on the history of the Barraba plant fossil locality and on the geology of the area. Many thanks to P. Gerrienne for his insightful comments on an early version of the manuscript and to $L$. Grauvogel-Stamm for her helpful advice about the structure of the spores. We thank Dermot Henry (Museum Victoria, Melbourne) for the loan of the specimen. Claude Gril (Electronic microscopy Service, University of Montpellier) is acknowledged for his technical help. Finally, we are very grateful to the two anonymous reviewers for their comments and suggestions that greatly improved the original manuscript.

\section{REFERENCES}

Arnold, C.A. 1933. A lycopodiaceous strobilus from the Pocono Sandstone of Pennsylvania. American Journal of Botany, 20:114-117.

Bateman, R.M. 1992. Morphometric reconstruction, palaeobiology and phylogeny of Oxroadia gracilis Alvin emend. and $O$. conferta sp. nov.: anatomically preserved rhizomorphic lycopsids from the Dinantian of Oxroad Bay, SE Scotland. Palaeontographica B, 228:29-103.

Bateman, R.M., DiMichele, W.A., and Willard, D.A. 1992. Experimental cladistic analysis of anatomically pre- 
served arborescent lycopsids from the Carboniferous of Euramerica: an essay on paleobotanical phylogenetics. Annals of the Missouri Botanical Garden, 79(3):500-559.

Bek, J. 2012. A review of the genus Lycospora. Review of Palaeobotany and Palynology, 174:122-135.

Bek, J. and Leary, R.L. 2012. Porostrobus nathorstii (Leary \& Mickle) emend. and its spores from the Namurian of Illinois, USA. Bulletin of Geosciences, 87(1):45-52.

Bek, J., Oplustil, S., Drabkova, J., and Psenicka, J. 2015. The sub-arborescent lycopsid Omphalophloios feistmantelii (O. Feistmantel) comb. nov. emend. from the Middle Pennsylvanian of the Czech Republic. Bulletin of Geosciences, 90(1):227-279.

Bek, J. and Straková, M. 1995. Carboniferous fertile branch Sporangiostrobus feistmantelii (O. Feistmantel) Nemejc and its miospores from the Kladno Basin, Bohemian massif. Acta musei Nationalis Pragae, Series B, Historia Naturalis, 51:37-51.

Bertrand, C E. 1891. Remarques sur le Lepidodendron harcourtii de Witham. Travaux et Mémoires de la Faculté de Lille, Volume II (Mémoire 6).

Bharadwaj, D.C. 1958. On Porostrobus zeilleri Nathorst and its spores with remarks on the systematic position of $P$. bennholdi Bode and the phylogeny of Densosporites Berry. Palaeobotanist, 7:67-75.

Bharadwaj, D.C. and Tiwari, R.S. 1970. Lower Gondwana megaspores - a monograph. Palaeontographica $B, 129: 1-70$.

Brack, S.D. and Taylor, T.N. 1972. The ultrastructure and organization of Endosporites. Micropaleontology, 18(1):101-109.

Brack-Hanes, S.D. and Thomas, B.A. 1983. A re-examination of Lepidostrobus Brongniart. Botanical Journal of the Linnean Society, 86:25-133.

Brousmiche-Delcambre, C., Coquel, R., and Wagner, R.H. 1995. Nouvelle interprétation du genre Omphalophloios White, 1898 (Lycophyte primitive). Comptes Rendus de l'Académie des Sciences Paris, série II a, 321:179-184.

Cai, C. and Chen, L. 1996. On a Chinese Givetian lycopod, Longostachys latisporophyllus $\mathrm{Zhu}, \mathrm{Hu}$ and Feng, emend:: its morphology, anatomy and reconstruction. Palaeontographica Abt B, 238:1-43.

Chaloner, W.G. 1953. A new species of Lepidostrobus containing unusual spores. Geological Magazine, XC(2):97-110.

Chaloner, W.G. 1958. Polysporia mirabilis Newberryi, a fossil lycopod cone. Journal of Paleontology, 32(1):199-209.

Chaloner, W.G. 1962. A Sporangiostrobus with Densosporites microspores. Palaeontology, 5(1):73-85.

Chaloner, W.G. 1967. Lycophyta, p. 435-781. In Boureau, E. (ed.), Traité de Paléobotanique. Masson et Cie, Paris.

Chaloner, W.G. 1968. The cone of Cyclostigma kiltorkense Haughton, from the Upper Devonian of Ire- land. Journal of the Linnean Society of London, Botany, 61(384):25-36.

Chambers, T.C. and Regan, M.A. 1986. Polyxylon australe - a new cladoxylalean axis from the Devonian of Australia. Australian Journal of Botany, 34:675-689.

Chestnut, W.S., Flood, R.H., and McKelvey, B.C. 1973. Manilla 1: 25 000, Geological Series, Sheet SH56-9, New South Wales Geological Survey.

Chitaley, S. and McGregor, D.C. 1988. Bisporangiostrobus harrisii gen. et sp. nov., an eligulate lycopsid cone with Duosporites megaspores and Geminospora microspores from the Upper Devonian of Pennsylvania, U.S.A. Palaeontographica Abt. B, 210 (4-6):127-149.

Chitaley, S. and Pigg, K.B. 1996. Clevelandodendron ohioensis, gen. et sp. nov., a slender upright lycopsid from the Late Devonian of Ohio. American Journal of Botany, 83(6):781-789.

Delevoryas, T. 1957. Anatomy of Sigillaria approximata. American Journal of Botany, 44(8):654-660.

DiMichele, W.A., Mahaffy, J.F., and Phillips, T.L. 1979. Lycopods of Pennsylvanian age coals: Polysporia. Canadian Journal of Botany, 57(16):1740-1753.

Dràbek, K. 1976. Polysporia mirabilis Newberry, 1873 from the Nýrany locality (Westphalian D). Casopis Národního Muzea, 146:93-96.

Dunn, M.T., Atkinson, P., Lacefield, J., and Rischbieter, M. 2012. Winslowia tuscumbiana gen. et sp. nov. (Chaloneriaceae): a cormose, heterosporous, ligulate lycopsid reconstructed from the inside out from the Pride Mountain Formation (Late Mississippian/ Serpukhovian) of Northern Alabama. International Journal of Plant Sciences, 173(1):96-111.

Fairon-Demaret, M. 1974. Nouveaux specimens du genre Leclercqia Banks, H.P., Bonamo, P.M. et Grierson, J.D., 1972 du Givétien (?) du Queensland (Australie). Bulletin de I'Institut Royal de Sciences Naturelles de Belgique, 50(2):1-4.

Fairon-Demaret, M. 1977. A new lycophyte cone from the Upper Devonian of Belgium. Palaeontographica Abt $B, 162(1-3): 51-63$.

Geng, B.-Y. 1990. New observations on Leptophloeum rhombicum from the Upper Devonian of Hubei, China. Acta Botanica Sinica, 32(12):951-956.

Gould, R.E. 1975. The succession of Australian pre-Tertiary megafossil floras. Botanical Review, 41(4):453483.

Grauvogel-Stamm, L. and Langiaux, J. 1995. Polysporia doubingeri n. sp., un nouvel organe reproducteur de lycophyte du Stéphanien (Carbonifère Supérieur) de Blanzy-Montceau (Massif Central, France). Sciences Géologiques, Bulletin, 48(1-3):63-81.

Grauvogel-Stamm, L. and Lugardon, B. 2004. The spores of the Triassic lycopsid Pleuromeia sternbergii (Münster) Corda: morphology, ultrastructure, phylogenetic implications, and chronostratigraphic inferences. International Journal of Plant Sciences, 165(4):631-650. 
Hao, S., Xue, J., Wang, Q., and Liu, Z. 2007. Yuguangia ordinata gen. et sp. nov., a new lycopsid from the Middle Devonian (Late Givetian) of Yunnan, China, and its phylogenetic implications. International Journal of Plant Sciences, 168(8):1161-1175.

Hill, R.S., Truswell, E.M., McLoughlin, S., and Dettmann, M. 1999. Evolution of the Australian flora: fossil evidence, p. 251-320. In Orchard, A.E. (ed.), Flora of Australia. Australian Government Publishing Service, Canberra.

Kenrick, P. and Crane, P. 1997. The origin and early evolution of plants on land. Nature, 389:33-39.

Lang, W.H. and Cookson, I.C. 1935. On a flora, including vascular land plants, associated with Monograptus, in rocks of Silurian age, from Victoria, Australia. Philosophical Transactions of the Royal Society of London, Series B, 224:421-449.

Leisman, G.A. 1970. A petrified Sporangiostrobus and its spores from the Middle Pennsylvanian of Kansas. Palaeontographica Abt. B, 129:166-177.

Lemoigne, Y. 1982. Le genre Leptophloeum Dawson, 1862 du Dévonien. Geobios, 15(1):33-41.

Li, X-X., Dou, Y-W., and Sun, Z-H. 1986. The genus Leptophloeum Dawson based on a recent study of new material from the Junggar Basin, Xinjiang. Acta Palaeontologica Sinica, 25:349-379.

Lu, L. 1981. An Upper Devonian spore and pollen assemblage from the Damaida area of Dukou, Province of Sichuan. Bulletin of the Nanjing Insitute of Geology and Palaeontology, Academia Sinica, 1981:91-130.

Lugardon, B., Grauvogel-Stamm, L., and Dobruskina, I. 1999. The microspores of Pleuromeia rossica Neuburg (Lycopsida; Triassic): Comparative ultrastructure and phylogenetic implications. Comptes Rendus de l'Académie des Sciences, Séries IIA, 329:435442.

Lugardon, B., Grauvogel-Stamm, L., and Dobruskina, I. 2000. Comparative ultrastructure of the megaspores of the Triassic lycopsid Pleuromeia rossica Neuburg. Comptes Rendus de l'Académie des Sciences, Séries IIA, 330:501-508.

Mathews, G.B. 1940. New Lepidostrobi from Central United States. Botanical Gazette, 102(1):26-49.

Meng, M., Wang, D., Xue, J., and Zhu, X. 2013. New insights and evolutionary significance of the megasporangiate strobilus of Minostrobus chaohuensis (Lycopsida) from the Upper Devonian of South China. Review of Palaeobotany and Palynology, 190:20-40.

Meyen, S. 1987. Fundamentals of Palaeobotany. Chapman and Hall, London.

Meyer-Berthaud, B., Decombeix, A-L., Dunstone, R., Gerrienne, P., Momont, N., and Young, G. 2016. Tetraxylopteris Beck emend. Hammond and Berry (2005), the first aneurophytalean genus recorded in Australia. Review of Palaeobotany and Palynology, 224:54-65.
Meyer-Berthaud, B., Fairon-Demaret, M., Steemans, P., Talent, J., and Gerrienne, P. 2003. The plant Leclercqia (Lycopsida) in Gondwana: implications for reconstructing Middle Devonian palaeogeography. Geological Magazine, 140(2):119-130.

Meyer-Berthaud, B., Soria, A., and Young, G.C. 2007. Reconsidering differences between Cladoxylopsida and Iridopteridales: evidence from Polyxylon australe (Upper Devonian, New South Wales, Australia). International Journal of Plant Sciences, 168(7):10851097.

Opluštil, S., Bek, J., and Schultka, S. 2010. Reexamination of the genus Omphalophloios White, 1898 from the Upper Silesian Coal Basin. Bulletin of Geosciences, 85(1):39-52.

Pigg, K.B. 1992. Evolution of isoetalean lycopsids. Annals of the Missouri Botanical Garden, 79:589612.

Pigg, K.B. 2001. Isoetalean lycopsid evolution: from the Devonian to the present. American Fern Journal, 91(3):99-114.

Pigg, K.B. and Rothwell, G.W. 1983a. Chaloneria gen. nov., heterosporous lycophytes from the Pennsylvanian of North America. Botanical Gazette, 144(1):132-147.

Pigg, K.B. and Rothwell, G.W. 1983b. Megagametophyte development in the Chaloneriaceae fam. nov., permineralized paleozoic isoetales (Lycopsida). Botanical Gazette, 144(2):295-302.

Prestianni, C. and Gess, R.W. 2014. The rooting system of Leptophloeum Dawson: new material from the Upper Devonian, Famennian Witpoort Formation of South Africa. Review of Palaeobotany and Palynology, 209:35-40.

Renault, B. 1888. Notice sur les Sigillaires. Bulletin de la Société d'Histoire Naturelle d'Autun, 1:121-199.

Rickards, R.B. 2000. The age of the earliest club mosses: the Silurian Baragwanathia flora in Victoria, Australia. Geological Magazine, 137(2):207-209.

Roy, B.A. and Matten, L.C. 1989. Lycopods from the New Albany Shale. Palaeontographica Abt B, 212:145.

Schlanker, C.M. and Leisman, G.A. 1969. The herbaceous Carboniferous lycopod Selaginella fraiponti comb. nov. Botanical Gazette, 130(1):35-41.

Scott, D.H. 1909. Studies in Fossil Botany (second edition). A. \& C. Black Limited, London.

Senkevitsch, M.A., Jurina, A.L., and Arkhangelskaya, A.D. 1993. On fructifications, morphology and anatomy of Givetian lepidophytes in Kazakhstan (USSR). Palaeontographica Abt B, 230:43-58.

Spinner, E. 1982. A new megaspore genus from the Lower Carboniferous (Asbian) of northern England. Journal of Micropalaeontology, 1:19-22.

Stevens, L.G., Hilton, J., Rees, A.R., Rothwell, G.W., and Bateman, R.M. 2010. Systematics, phylogenetics, and reproductive biology of Flemingites arcuatus sp. nov., an exceptionally preserved and partially reconstructed Carboniferous arborescent lycopsid. Inter- 
national Journal of Plant Sciences, 171(7):783-808.

Traverse, A. 2008. Paleopalynology (second edition). Springer, Dordrecht, The Netherlands.

Taylor, T.N., Taylor, E.L., and Krings, M. 2009. Paleobotany. The Biology and Evolution of Fossil Plants (second edition). Academic Press, Amsterdam.

Vickery, N.M., Brown, R.E., and Percival, I.G. 2010. Explanatory Notes. Manilla 1:100 000 geology sheet 9036. Geological Survey of New South Wales Sydney.

Wagner, R.H. 1989. A late Stephanian forest swamp with Sporangiostrobus fossilized by volcanic ash fall in the Puertollano Basin, central Spain. International Journal of Coal Geology, 12:523-552.

Walton, J. 1925-1926. On some Australian fossil plants referable to the genus Leptophloeum Dawson. Manchester Memoirs, 70(10):113-123.

Wang, D-M., Meng, M., Xue, J., Basinger, J.F., Guo, Y., and Liu, L. 2014. Changxingia longifolia gen. et sp. nov., a new lycopsid from the Late Devonian of Zhejiang Province, South China. Review of Palaeobotany and Palynology, 203:35-47.

Wang, Q., Geng, B.-Y., and Dilcher, D.L. 2005. New perspective on the architecture of the Late Devonian arborescent lycopsid Leptophloeum rhombicum (Leptophloaceae). American Journal of Botany, 92(1):83-91.

Wang, Q., Li, C-S., Geng, B., and Chitaley, S. 2003. A new species of Lepidostrobus from the Upper Devonian of Xinjiang, China and its bearing on the phylogenetic significance of the order Isoëtales. Botanical Journal of the Linnean Society, 143:55-67.

Wang, Y. 2001. A new lycopsid megaspore cone from the Upper Devonian of Chaohu, China. Botanical Journal of the Linnean Society, 136(1):439-448.

White, M.E. 1986. The Greening of Gondwana. Reed Books Pty, French Forests, New South Wales.

Wright, A.J. 1988. First report of Late Devonian trilobites from eastern Australia. Proceedings of the Linnean Society of New South Wales, 110(1):27-30.

Young, G.C. 2007. Devonian formations, vertebrate faunas and age control on the far south coast of New South Wales and adjacent Victoria. Australian Journal of Earth Sciences, 54(7):991-1008.

Zeiller, M.R. 1911. Etude sur le Lepidostrobus brownii (Unger) Schimper. Mémoire de l'Académie des Sciences, 152:1-67. 